\title{
Tumor-Associated Macrophage Promotes Tumor Progression via STAT3 Signaling in Hepatocellular Carcinoma
}

\author{
Yohei Mano ${ }^{a}$ b Shinichi Aishima ${ }^{a}$ Nobuhiro Fujita ${ }^{c}$ Yuki Tanaka ${ }^{a}$ \\ Yuichiro Kubo $^{a}$ Takashi Motomura $^{\mathrm{b}}$ Akinobu Taketomi ${ }^{\mathrm{b}}$ Ken Shirabe ${ }^{\mathrm{b}}$ \\ Yoshihiko Maehara ${ }^{b}$ Yoshinao Oda ${ }^{a}$

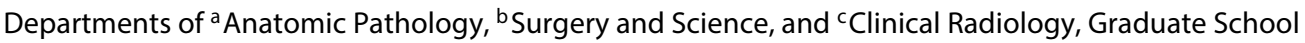 \\ of Medical Sciences, Kyushu University, Fukuoka, Japan
}

\section{Key Words}

Hepatocellular carcinoma · STAT3 · Macrophage

\section{Abstract}

Objective: Signal transducer and activator of transcription 3 (STAT3) is activated in hepatocellular carcinoma (HCC), and tumor-associated macrophage plays an important role in tumor progression. Therefore, we examined STAT3 activation, cytokine expression and infiltration of tumor-associated macrophages in resected HCCs as well as the alteration of cell growth and migration by cytokine stimulation in HCC cell lines. Methods: Immunohistochemical staining of phosphorylated STAT3 (pSTAT3), CD163, interleukin (IL)-6, Ki-67 and BCl-XL was performed for 101 cases of resected HCC, and correlations between PSTAT3 staining and clinicopathological findings were analyzed. In HCC cell lines (PLC/ $\mathrm{PRF} / 5$ and Huh7), cell proliferation and migration by IL-6 stimulation and S3I-201 (STAT3 inhibitor) treatment were analyzed. Results: In HCC specimens, the PSTAT3-positive group showed high levels of a-fetoprotein ( $p=0.0276)$, large tumor size $(p=0.0092)$, frequent intrahepatic metas- tasis $(\mathrm{p}=0.0214)$, high Ki-67 $(\mathrm{p}=0.0002)$ and $\mathrm{Bcl}-\mathrm{XL}(\mathrm{p}=$ $0.0001)$, poor prognosis $(p=0.0234)$, and high recurrence rate $(p=0.0003)$. CD163-positive cells were frequently observed in the PSTAT3-positive group $(p=0.0013)$. In two HCC cell lines, IL- 6 stimulation promoted cell proliferation and migration via the STAT3 phosphorylation, and S3I-201 inhibited this activation. Conclusions: STAT3 activation was correlated with aggressive behavior of HCC and may be mediated via tumor-associated macrophage. We expect that STAT3 signaling and tumor-associated macrophages can be attractive therapeutic targets in HCC patients.

Copyright $\odot 2013$ S. Karger AG, Basel

\section{Introduction}

Hepatocellular carcinoma (HCC) is the fifth most common cause of cancer in the world [1]. Although surgical therapies for HCC have progressed and outcomes of HCC have improved, HCC still often recurs after surgery $[2,3]$. Sorafenib, one of the molecular targeted therapies, was reported to show activity against unresectable HCCs;

\section{KARGER}

Fax +41613061234

E-Mail karger@karger.ch

www.karger.com
(C) 2013 S. Karger AG, Basel

1015-2008/13/0803-0146\$38.00/0

Accessible online at:

www.karger.com/pat
Yoshinao Oda, $\mathrm{PhD}$

Department of Anatomic Pathology

Graduate School of Medical Sciences, Kyushu University

3-1-1 Maidashi, Higashi-ku, Fukuoka 812-8582 (Japan)

E-Mail oda@ surgpath.med.kyushu-u.ac.jp 
however, its survival advantage is only 3.7 months [4]. New therapeutic targets are required to improve the survival of patients with HCC.

Signal transducer and activator of transcription 3 (STAT3) is an important molecule in tumor progression [5]. STAT3 activation occurs via phosphorylation and dimerization of tyrosine residue (Tyr705), leading to nuclear entry, DNA binding and gene transcription. STAT3 was regarded as a critical transcription activator for cell cycleor cell survival-related genes. Bcl-XL is an antiapoptotic protein transcribed by STAT3 activation [6]. Some cytokines such as interleukin (IL)-6 or IL-10 activate STAT3 signaling via their receptors [7]. Constitutive activation of STAT3 has been demonstrated to contribute to tumorigenesis in breast cancer [8], colon cancer [9], lung cancer [10], pancreatic cancer [11], prostate cancer [12], and melanoma [13]. In human HCC, STAT3 phosphorylation was also detected and related to tumor progression [14], angiogenesis [15] and tumorigenesis [16]. The tumor microenvironment is closely associated with the growth of tumor cells, and tumor-associated macrophages play an important role in tumor progression [17]. Macrophages are major inflammatory cells that infiltrate tumors; several studies have shown that high infiltration of tumor-associated macrophages was associated with tumor progression and metastasis [17-20] and predicts poor prognosis in patients with HCC [21]. Tumor-associated macrophages activate STAT3 in ovarian cancer [22] and glioblastoma [23]. However, the correlation between tumor-associated macrophages and STAT3 activation of HCC tumor cells is unknown. Therefore, we examined STAT3 activation, cytokine expression and infiltration of tumor-associated macrophages in resected HCCs and analyzed their association with clinicopathological findings. Alterations in cell growth and migration by cytokine stimulation and STAT3 inhibitor were also analyzed in HCC cell lines.

\section{Materials and Methods}

\section{Patients and Samples}

One hundred and one available paraffin-embedded specimens from patients with HCC who underwent hepatectomy between January 1997 and December 2001 in our institute were selected by reviewing their pathology data. Any patients undergoing previous or noncurative surgery were excluded. After the surgery, monthly measurement of the serum $a$-fetoprotein (AFP) level was performed. In addition, ultrasonography and dynamic CT were performed every 3 months. The postoperative survival period or recurrence was entered into the database immediately when a patient died or if recurrence was strongly suspected on diagnostic imaging such as CT or magnetic resonance imaging.

TAM and STAT3 Activation in HCC
This study conformed to the ethical guidelines of the $1975 \mathrm{Dec}-$ laration of Helsinki and was approved by the ethics committees of Kyushu University Hospital (grant No. 21-117). Informed consent was obtained from each patient included in the study.

\section{Immunohistochemistry}

Sections of resected specimens were fixed in $10 \%$ buffered formalin, embedded in paraffin and stained by Envision+ system and DAB kit (Dako, Glostrup, Denmark). Immunohistochemical stains were performed with antibodies of phosphorylated STAT3 (pSTAT3; Tyr 705; D3A7, 1:50; Cell Signaling Technology), CD163 (10D6, 1:200; Novocastra), IL-6 (rabbit polyclonal, 1:1,000; Abcam), Ki-67 (MIB-1, 1:200; Dako), and Bcl-XL (rabbit polyclonal, 1:200; Santa Cruz Biotechnology, Santa Cruz, Calif., US). Sections were pretreated before being incubated with primary antibodies in a microwave oven at $99^{\circ} \mathrm{C}$ for $20 \mathrm{~min}$ for pSTAT3, CD163, IL-6 and $\mathrm{Bcl}-\mathrm{XL}$ or in a pressure cooker for $25 \mathrm{~min}$ for Ki- 67.

Each slide was stained in serial sections and examined by two pathologists (Y.M. and S.A.). In nuclear staining of pSTAT3 and $\mathrm{Ki}-67$ and in cytoplasm staining of Bcl-XL, the percent positive cells was estimated by count of 1,000 tumor cells in most staining areas (hot spots). Staining of CD163, a marker of tumor-associated macrophages [19,22-25], and IL-6 was evaluated by estimating the total counts of cytoplasm or membrane at 3 high-power fields. The mean of nuclear pSTAT3-positive cells in HCCs was 10.7\% (range $0-82.0)$, and pSTAT3 stain was classified into a positive $(\geq 10.7 \%$ of tumor cell nuclei) and a negative group $(<10.7 \%$ of tumor nuclei). Furthermore, in the cases of the pSTAT3-positive group ( $\mathrm{n}=$ 36), the CD163-positive cells were counted separately in areas of pSTAT3-positive and pSTAT3-negative HCC cells.

For double staining of IL- 6 and CD163, HCC specimens were boiled in $10 \mathrm{mM}$ citrate buffer ( $\mathrm{pH}$ 6.0) for $20 \mathrm{~min}$ and incubated with IL-6 primary antibody $(1: 1,000)$ at room temperature for 15 $\min$. The sections were washed three times and incubated with anti-rabbit horseradish peroxidase-conjugated polymer at room temperature for $45 \mathrm{~min}$; IL- 6 was visualized by DAB kit. Next, the sections were boiled in $10 \mathrm{mM}$ citrate buffer ( $\mathrm{pH} \mathrm{6.0)}$ for $10 \mathrm{~min}$, incubated with CD163 primary antibody (1:200) for $90 \mathrm{~min}$ and incubated with anti-mouse alkaline phosphatase-conjugated polymer at room temperature for $45 \mathrm{~min}$. CD163 of the sections was visualized by New Fuchsin Substrate kit (Nichirei, Tokyo, Japan).

\section{Cell Culture}

Human HCC cell lines PLC/PRF/5 and Huh7 were obtained from Riken Bioresource Center, Tsukuba, Japan, and cultured in Dulbecco's modified Eagle's medium (DMEM) supplemented with 1 or $10 \%$ fetal bovine serum (FBS). PLC/PRF/5 and Huh7 cells were maintained in DMEM containing $1 \%$ FBS for $24 \mathrm{~h}$ prior to IL-6 (Peprotech, Rocky Hill, N.J., USA) stimulation. All in vitro experiments were done in triplicate.

\section{Immunoblotting}

Cellular proteins were solubilized in lysis buffer containing protease inhibitor and phosphatase inhibitor $30 \mathrm{~min}$ after stimulation with IL-6 $(20 \mu \mathrm{g} / \mathrm{ml})$. Equal amounts of protein were separated by SDS-PAGE and then transferred to the polyvinylidene fluoride membrane. Following blocking in Tris buffer containing $2 \%$ BSA, the membrane was stained with 1:1,000 dilution of antiSTAT3 (Cell Signaling Technology, Danvers, Mass., USA) and anti-pSTAT3 (Cell Signaling Technology) antibodies, then 


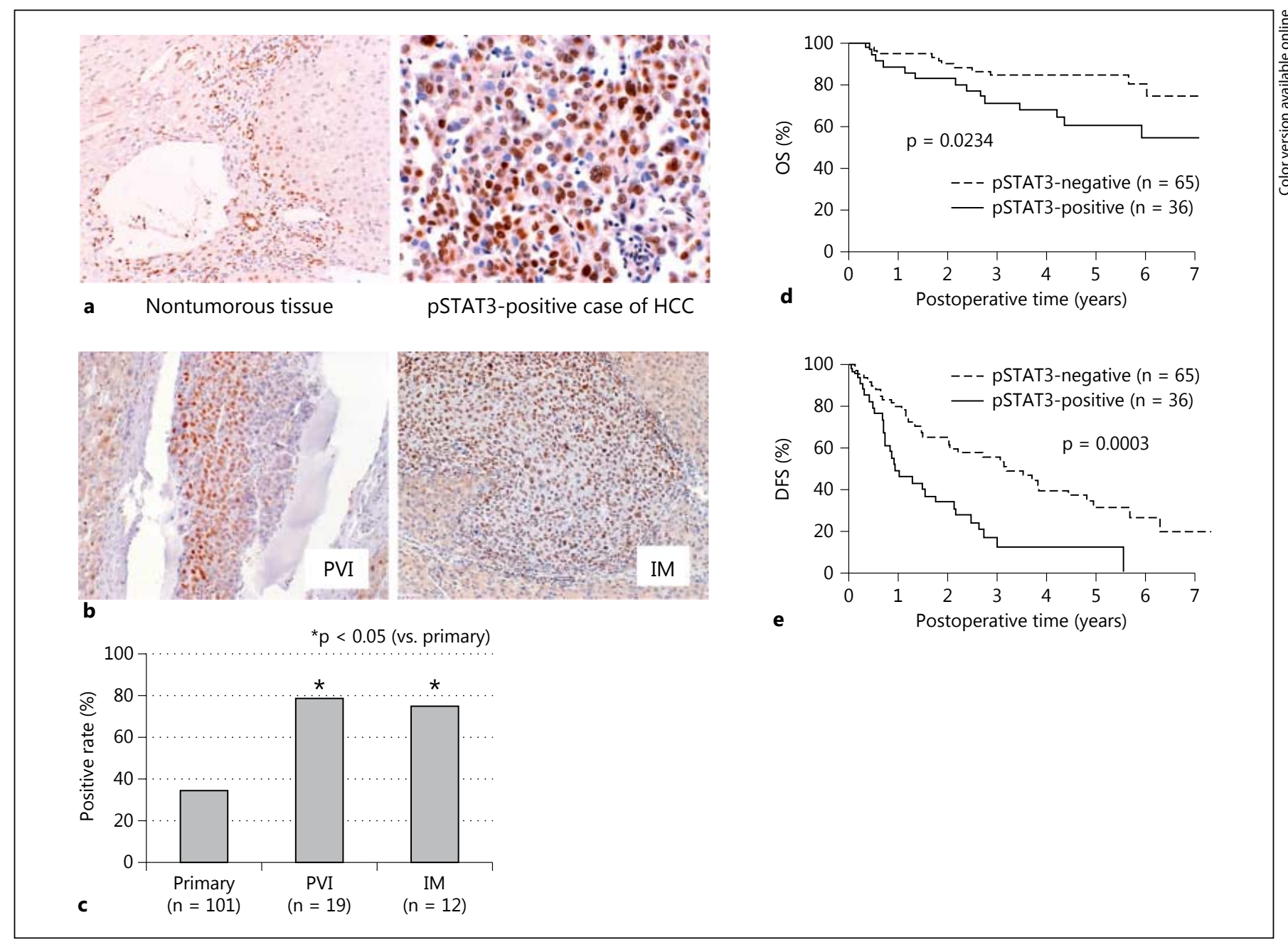

Fig. 1. Immunohistochemical staining of pSTAT3 in HCC. a pSTAT3 was expressed in the nucleus. In nontumorous tissue, endothelial cells, bile duct epithelial cells and inflammatory cells were stained by pSTAT3 (left panel). $\times 100$. HCC cells were also stained $(82.2 \%$, right panel). $\times 100$. b Tumor cells of PVI and IM stained by pSTAT3. $\times 200$. c Comparison of pSTAT3 staining in primary

washed and incubated with horseradish peroxidase-conjugated secondary antibody (Cell Signaling Technology). Bands were visualized by the enhanced chemiluminescence system (GE Healthcare, UK).

\section{Cell Growth Assay}

$\mathrm{PLC} / \mathrm{PRF} / 5$ and Huh7 cells were seeded at a density of $5 \times 10^{4}$ cells/24-well plates and maintained in conditioned medium for 24 $\mathrm{h}$ before stimulation. Viable cells were counted by trypan blue stain $48 \mathrm{~h}$ after stimulation with IL-6 $(25 \mathrm{ng} / \mathrm{ml})$.

Wound-Healing Assay

PLC/PRF/5 and Huh7 cells were seeded at a density of $5 \times 10^{4}$ cells/6-well plates. Approximately $24 \mathrm{~h}$ later, when the cells were $100 \%$ confluent, a sterile $100-\mu$ l pipette tip was used to longitudi-
HCC, tumor cells of PVI and IM. pSTAT3 staining was significantly prominent in tumor cells of PVI and IM compared with primary HCC $(\mathrm{p}<0.05)$. d, e pSTAT3 expression correlated with poor prognosis. OS (d) and DFS (e) curves for pSTAT3-positive and pSTAT3-negative groups in patients with $\operatorname{HCC}(\mathbf{d}, \mathrm{p}=0.0234$; e, $\mathrm{p}=0.0003$; log-rank test). nally scratch a constant-diameter strip in the confluent monolayer. The medium and cell debris were aspirated away and replaced by 2 $\mathrm{ml}$ of fresh DMEM containing 1\% FBS with or without IL-6 (25 ng/ $\mathrm{ml}$ ). Photographs were taken at 0 and $48 \mathrm{~h}$ after wounding by phase-contrast microscopy. For statistical analysis, three randomly selected points along each wound were marked, and the horizontal distance between the migrating cells and the initial wound was measured $48 \mathrm{~h}$ later.

\section{Inhibition of STAT3}

In both cell growth and wound-healing assays, PLC/PRF/5 and Huh7 cells were cultured in DMEM containing 1\% FBS and IL-6 $(25 \mathrm{ng} / \mathrm{ml})$ with or without $100 \mathrm{nM} \mathrm{S3I-201}$ (NSC 74859; Santa Cruz Biotechnology). S3I-201 was treated 30 min before IL-6 stimulation. DMSO was used for control. 
Table 1. Comparison of pSTAT3 expression and clinicopathological findings

\begin{tabular}{|c|c|c|c|}
\hline pSTAT3 expression & $\begin{array}{l}\text { pSTAT3 negative } \\
(\mathrm{n}=65)\end{array}$ & $\begin{array}{l}\text { pSTAT3 positive } \\
(\mathrm{n}=36)\end{array}$ & $\begin{array}{l}\mathrm{p} \\
\text { value }\end{array}$ \\
\hline \multicolumn{4}{|l|}{ Clinical features } \\
\hline Sex, male/female & $55 / 10$ & $26 / 10$ & 0.0849 \\
\hline Age, years & $63.9 \pm 7.3$ & $63.6 \pm 9.5$ & 0.8726 \\
\hline HBsAg, +/- & $14 / 51$ & $8 / 28$ & 0.9922 \\
\hline $\mathrm{HCV} \mathrm{Ab},+/-$ & $42 / 23$ & $23 / 13$ & 0.9798 \\
\hline Cirrhosis & $22 / 43$ & $14 / 22$ & 0.4990 \\
\hline $\mathrm{AFP}, \mathrm{ng} / \mathrm{ml}$ & $852.4 \pm 308^{\dagger}$ & $20,673.4 \pm 11,688^{\dagger}$ & $0.0276^{\star}$ \\
\hline $\mathrm{DCP}, \mathrm{mAU} / \mathrm{ml}$ & $2,798.2 \pm 1,179.1^{\dagger}$ & $6,278.4 \pm 3,184.7^{\dagger}$ & 0.2217 \\
\hline \multicolumn{4}{|l|}{ Pathological features } \\
\hline Tumor size, $\mathrm{cm}$ & $3.7 \pm 2.2$ & $5.1 \pm 3.2$ & $0.0092^{\star}$ \\
\hline $\begin{array}{l}\text { Differentiation, } \\
\text { poor/well and } \\
\text { moderate }\end{array}$ & $19 / 46$ & $16 / 20$ & 0.1253 \\
\hline Capsule formation & $41 / 24$ & $26 / 10$ & 0.4619 \\
\hline $\begin{array}{l}\text { Infiltration to } \\
\text { the capsule }\end{array}$ & $33 / 32$ & $23 / 13$ & 0.1681 \\
\hline Portal venous & & & \\
\hline $\begin{array}{l}\text { invasion, +/- } \\
\text { Hepatic venous }\end{array}$ & $30 / 35$ & $24 / 12$ & 0.0687 \\
\hline $\begin{array}{l}\text { invasion, +/- } \\
\text { Intrahepatic }\end{array}$ & $15 / 50$ & $12 / 24$ & 0.3031 \\
\hline metastasis, +/- & $18 / 47$ & $18 / 18$ & $0.0214^{*}$ \\
\hline MIB-1 LI, \% & $3.5 \pm 0.5$ & $10.2 \pm 2.2$ & $0.0002^{\star}$ \\
\hline Bcl-XL, \% & $13.0 \pm 1.5$ & $25.2 \pm 2.0$ & $0.0001^{\star}$ \\
\hline
\end{tabular}

HBsAg = Hepatitis B surface antigen; HCV Ab = hepatitis C virus antibody; DCP $=$ des- $\gamma$-carboxy prothorombin. ${ }^{*} \mathrm{p}<0.05$.

\section{Statistical Analysis}

Statistical analysis was carried out using Microsoft Excel software and JMP software (SAS Institute, Cary, N.C., USA). Comparison between pSTAT3 staining and clinicopathological findings or staining of other antibodies was evaluated by Pearson's $\chi^{2}$, Fisher's exact tests and the Mann-Whitney U test. Patient survival analysis including overall survival (OS) and disease-free survival (DFS) was calculated by the Kaplan-Meier method; differences were evaluated by the log-rank test. For multivariate analysis, the Cox proportional hazard model was used. Two-sided Student's t test was applied for analysis of in vitro data. Statistical analyses were considered significant at a $\mathrm{p}$ value $<0.05$.

\section{Results}

\section{pSTAT3 Expression in Clinical Samples}

pSTAT3 was stained in the nuclei of HCC cells, normal endothelial cells, some bile duct epithelial cells and inflammatory cells. pSTAT3 nuclear staining in HCC cells is displayed in figure 1a. The mean percentage of nuclear pSTAT3-positive cells in HCCs was $10.7 \%$ (range $0-82.0$ ). The number of pSTAT3-positive and pSTAT3-negative samples was 36 and 65, respectively. We also examined pSTAT3 staining at the lesions of 19 portal venous invasions (PVIs) and 12 intrahepatic metastases (IMs) in 101 cases. Fifteen of 19 PVIs (78.9\%) and 9 of $12(75.0 \%)$ IMs were defined as pSTAT3-positive cases (fig. 1b). Positive rates in both lesions were significantly higher than those in the primary lesions (35.6\%; $\mathrm{p}<0.05$; fig. $1 \mathrm{c})$.

\section{Comparison of pSTAT3 Expression and \\ Clinicopathological Findings}

A comparison of clinicopathological findings in pSTAT3-positive and pSTAT3-negative groups is summarized in table 1 . The pSTAT3-positive group showed higher AFP $(p=0.0276)$, larger tumor size $(p=0.0092)$, more frequent IMs $(\mathrm{p}=0.0214)$, a higher Ki-67 labeling index (LI; $p=0.0002)$, and more Bcl-XL-positive cells ( $\mathrm{p}$ $=0.0001$ ) than the pSTAT3-negative group, whereas no significant differences were noted with respect to sex, age, infection of hepatitis viruses, liver cirrhosis, PIVKA II (proteins induced by vitamin $\mathrm{K}$ absence or antagonist II), histological differentiation, capsule formation, infiltration to the capsule, and vessel invasion.

\section{Survival Analysis after Surgery}

The median follow-up period was 1,391 days (range 36-3,289). pSTAT3 expression was significantly correlated with OS and DFS ( $\mathrm{p}=0.0234$ and 0.0003 , respectively; fig. 1d, e). Univariate analyses indicated that high AFP $(>100 \mathrm{ng} / \mathrm{ml})$, large tumor size $(>5 \mathrm{~cm})$, PVIs and IMs were prognostic factors for OS and male sex, hepatitis C virus infection, high AFP (>100 ng/ml) and IMs for DFS (table 2). Multivariate proportional hazard models revealed that high AFP and IMs were independent prognostic factors for OS and pSTAT3 expression and high AFP for DFS (table 2).

\section{Tumor-Associated Macrophage Localization and}

pSTAT3 Expression of HCCs

CD163-positive cells were localized around the pSTAT3-positive HCC cells (fig. 2a). Figure 2b shows the boxplots of CD163-positive cells (mean \pm SD: pSTAT3negative group, $28.5 \pm 15.4$; pSTAT3-positive group, 42.6 $\pm 26.6)$. The pSTAT3-positive group $(n=36)$ showed statistically higher CD163-positive cells $(\mathrm{p}=0.0013$; fig. $2 b)$ than the pSTAT3-negative group $(n=65)$. Furthermore, we analyzed the localization of CD163-posi- 


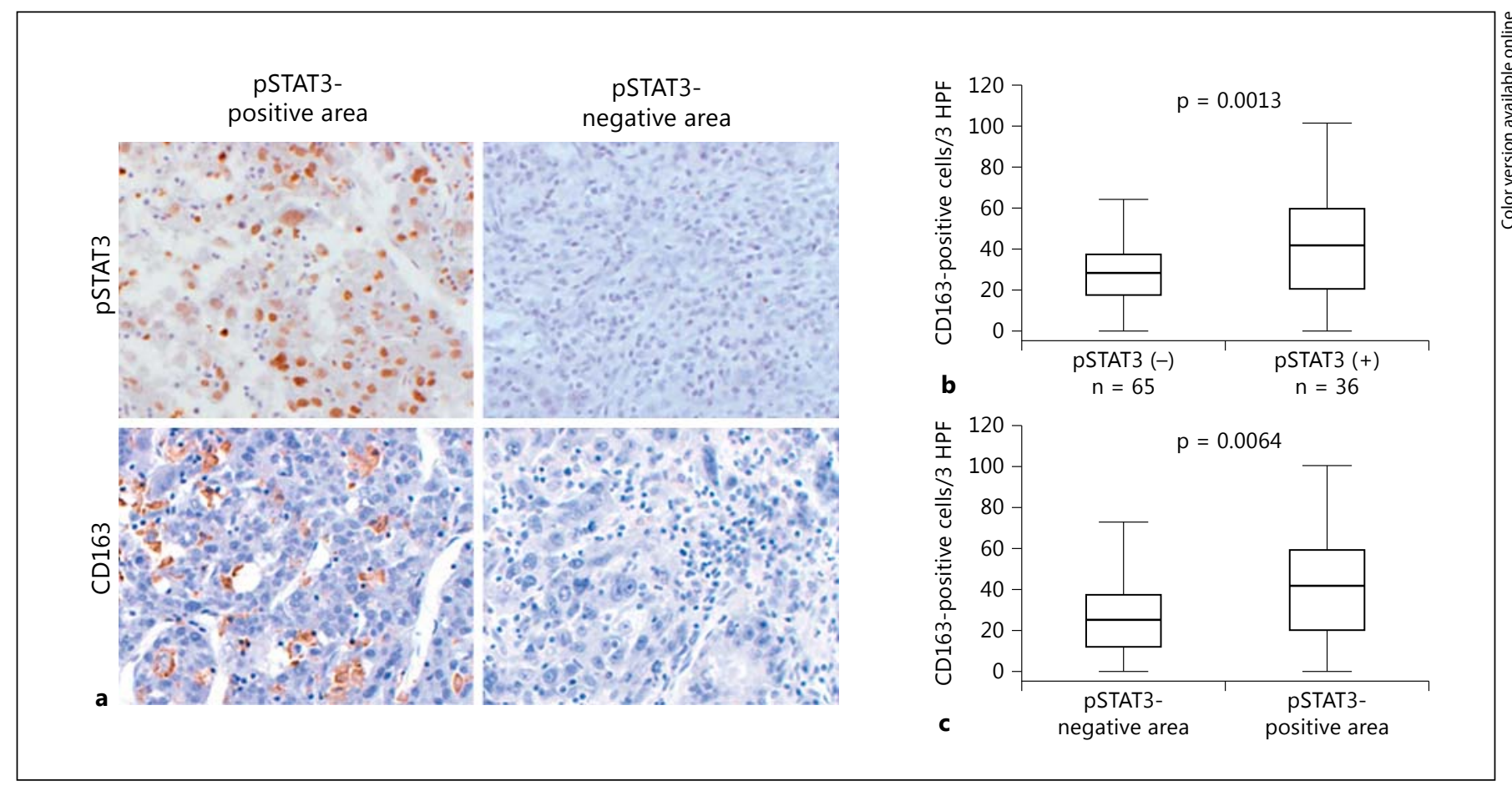

Fig. 2. Tumor-associated macrophages correlated with pSTAT3 expression in HCC. a Immunohistochemical staining of pSTAT3 and CD163 in the pSTAT3-positive and pSTAT3-negative area. $\times 200$. b Counts of CD163-positive cells between pSTAT3-positve and pSTAT3-negative groups. c Counts of CD163-positive cells in areas of pSTAT3-positive and pSTAT3-negative HCC cells existed in the pSTAT3-positive group. HPF = High-power field.

Table 2. Survival analysis after surgery

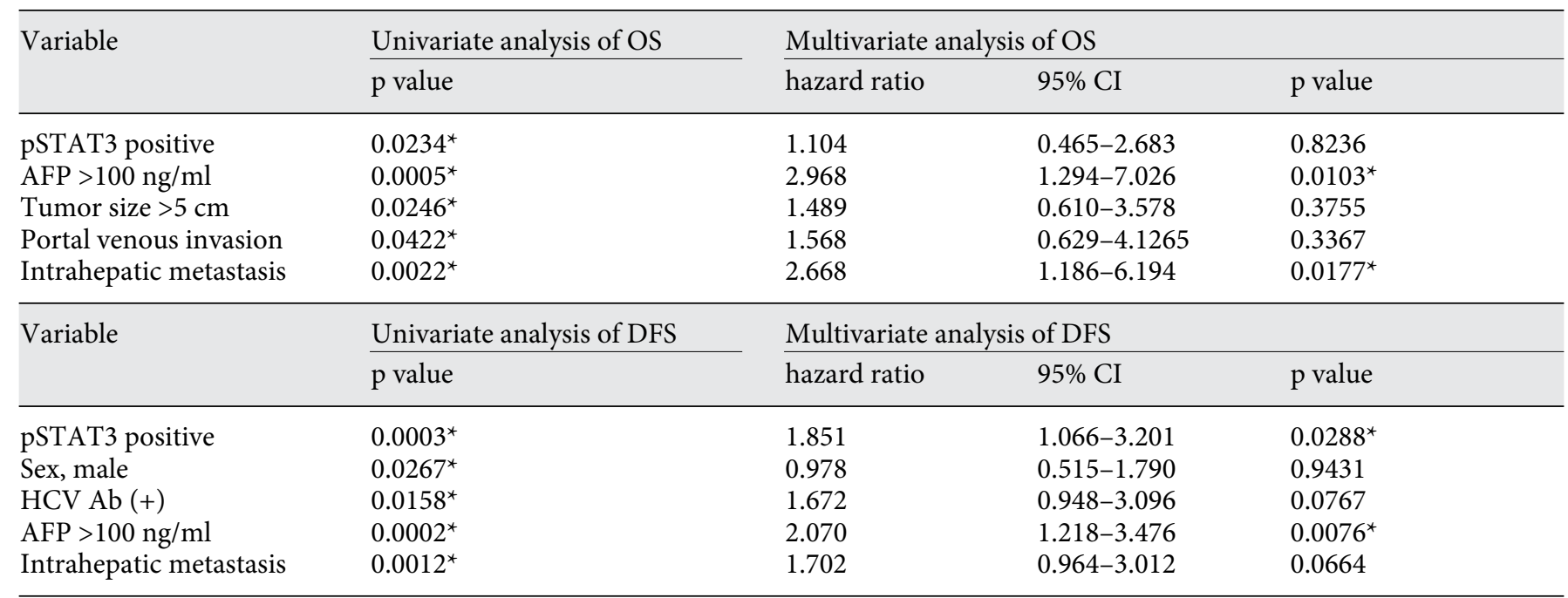

$\mathrm{CI}=$ Confidence interval; $\mathrm{HCV} \mathrm{Ab}=$ hepatitis $\mathrm{C}$ virus antibody. ${ }^{\star} \mathrm{p}<0.05$. 

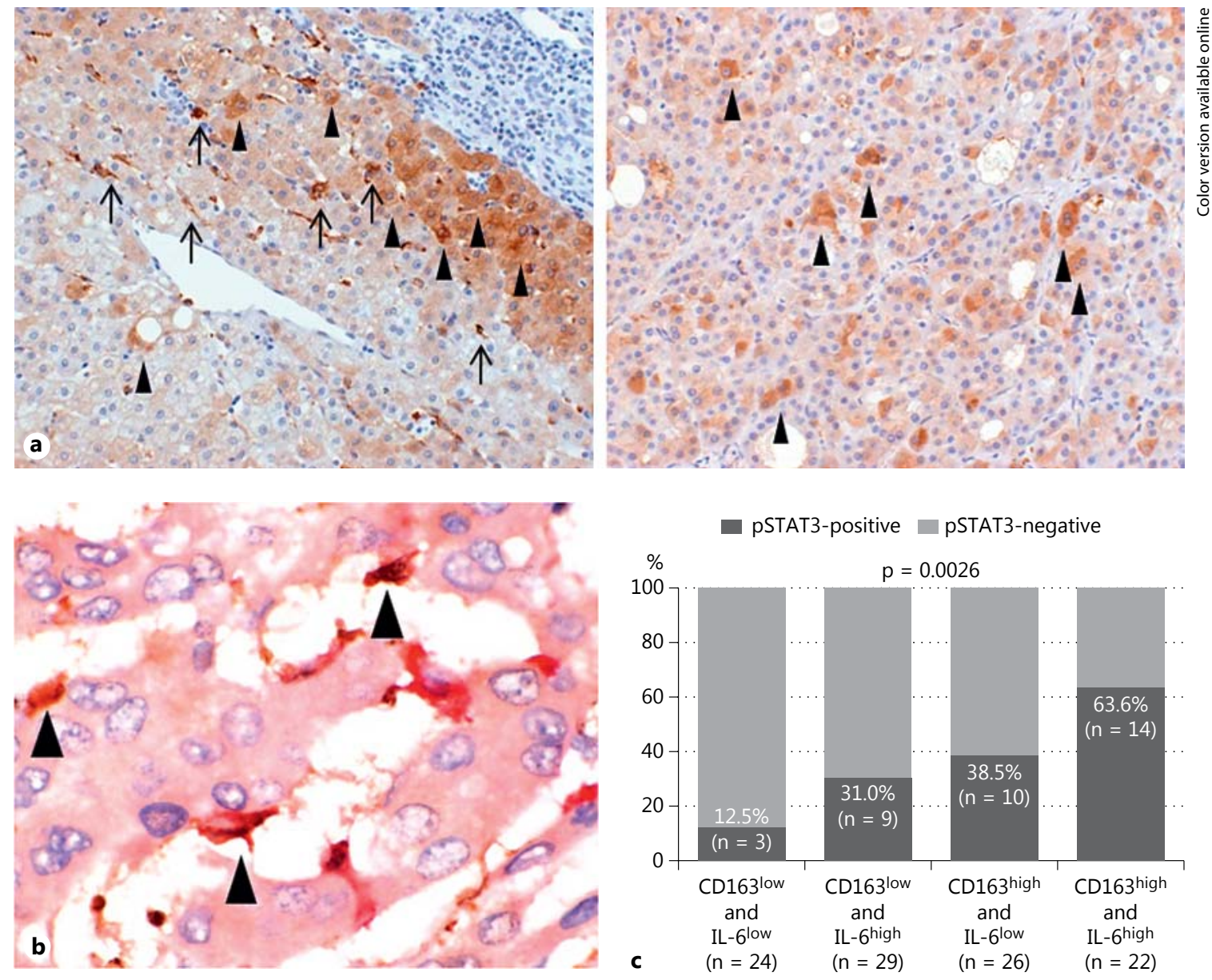

Fig. 3. Tumor-associated macrophages expressed IL-6. a Immunohistochemical staining of IL- 6 in HCC. $\times 200$. Not only macrophages (arrows, left panel) but also some hepatocytes (arrowheads, left panel) and some tumor cells (arrowheads, right panel) showed immunoreactivities for IL-6. b Double staining of IL-6 (red) and CD163 (brown). $\times 400$. Double-positive cells (arrowheads) were frequently seen in the tumor. c Correlation between pSTAT3-positive and IL-6/CD163-positive staining.

tive cells in areas where pSTAT3-positive and pSTAT3negative HCC cells existed in the pSTAT3-positive group $(\mathrm{n}=36)$, and figure $2 \mathrm{c}$ shows the boxplots of the analyses (mean \pm SD:pSTAT3-negative area, $27.7 \pm 17.9$; pSTAT3positive area, $42.6 \pm 26.6$ ). In the pSTAT3-positive group, CD163-positive cells in areas where pSTAT3-positive HCC cells existed were statistically higher than in those where pSTAT3-negative HCC cells existed ( $p=0.0064$; fig. 2c).

\section{Cytokine Expression of Macrophages}

IL-6 was stained in some macrophages, HCC cells and normal hepatocytes (fig. 3a). According to the double staining of CD163 and IL-6, CD163-positive cells (tumor-associated macrophages) expressed IL-6 (fig. 3b).
We divided them into two by the median values of positive macrophages of IL- 6 and CD163, and thereby classified the 101 cases into four groups such as $\mathrm{CD} 163^{\text {low }}$ and IL- $6^{\text {low }}, \mathrm{CD} 163^{\text {low }}$ and IL-6 $6^{\text {high }}, \mathrm{CD} 163^{\text {high }}$ and IL- $6^{\text {low }}$, and CD163 $3^{\text {high }}$ and IL- $6^{\text {high }}$. HCCs containing high infiltration of IL-6- and CD163-positive macrophages exhibited a significantly higher rate of positive staining for pSTAT3 (fig. 3c).

\section{IL-6 Stimulates Cell Proliferation and Migration of Human HCC Cell Lines}

IL-6 stimulation increased the levels of pSTAT3 in both PLC/PRF/5 and Huh7 HCC cell lines (fig. 4a). IL-6 stimulation resulted in higher proliferation (fig. $4 \mathrm{~b}$ ) and greater migration distance (fig. 4c) versus control. S3I- 


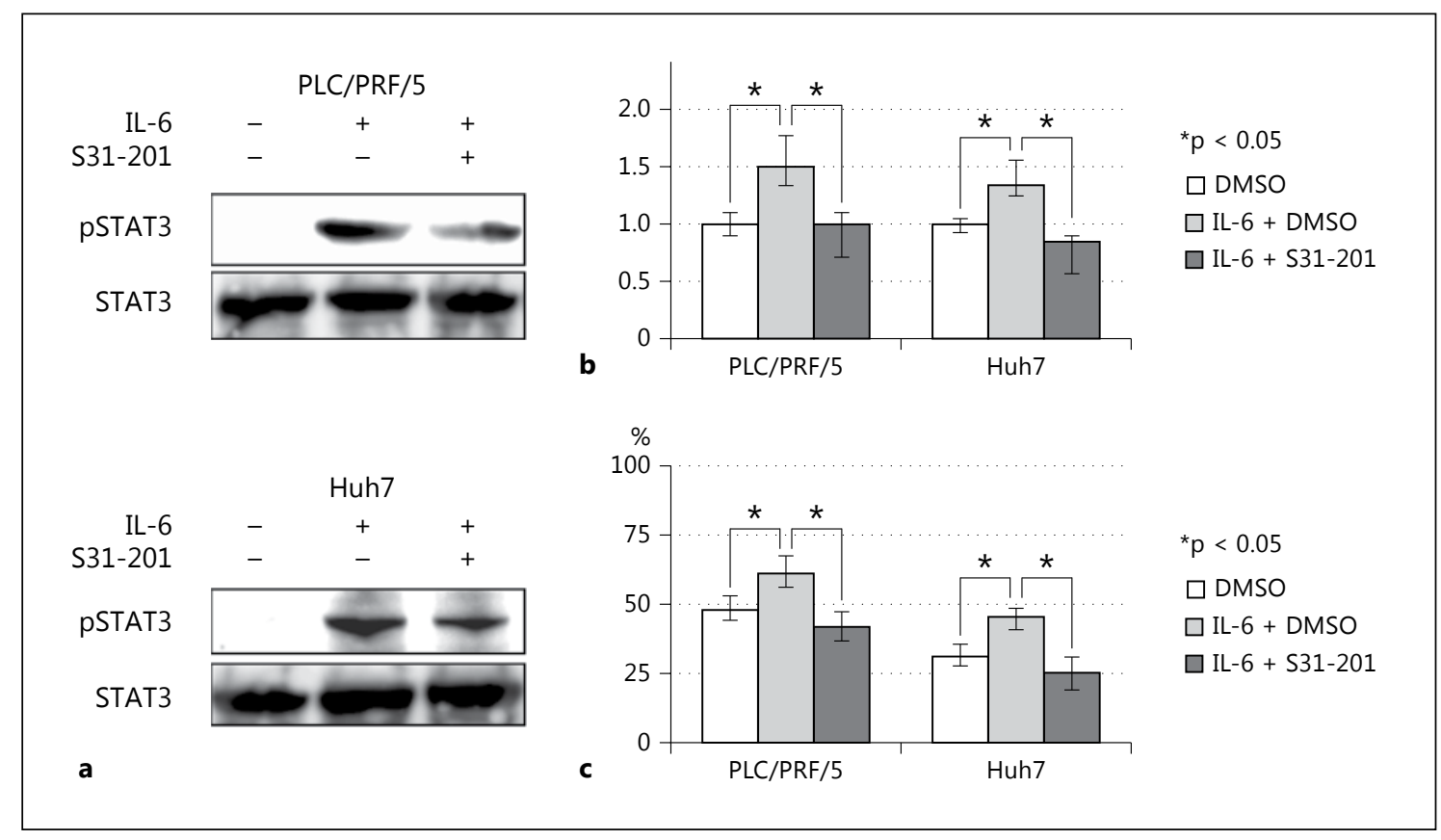

Fig. 4. IL-6 stimulation activated STAT3 signaling and promoted cell proliferation and migration in HCC cell lines. a PLC/PRF/5 (upper panel) and Huh7 (lower panel) were treated with $25 \mathrm{ng} / \mathrm{ml} \mathrm{IL-6}$ for $30 \mathrm{~min}$. b PLC/PRF/5 and Huh7 were cultured with $25 \mathrm{ng} / \mathrm{ml} \mathrm{IL-6,} 100 \mathrm{nM}$ S3I-201 and conditioned medium (1\% FBS); cell proliferation was evaluated $48 \mathrm{~h}$ after IL-6 stimulation. Control set at 1. c PLC/PRF/5 and Huh7 were cultured with $25 \mathrm{ng} / \mathrm{ml}$ IL-6, $100 \mathrm{nM}$ S3I-201 and conditioned medium (1\% FBS), and wound-healing assay was evaluated $48 \mathrm{~h}$ thereafter.

201, a STAT3 inhibitor, inhibited IL-6-induced STAT3 phosphorylation (fig. 4a) and decreased proliferation and migration of HCC cell lines (fig. 4b, c).

\section{Discussion}

Our results suggest that macrophage infiltration into HCC tissue stimulates tumor cells via STAT3 signaling. In the present study, pSTAT3-positive HCCs show malignant behavior and confer poor prognosis because of their high abilities of cell proliferation and migration. We found that high PSTAT3 expression was significantly correlated with larger tumor size, higher Ki-67 LI, higher Bcl-XL expression and greater frequency of IMs, and higher pSTAT3 expression was observed in the lesions of IMs and PVIs than in the primary lesions. STAT3 activation upregulates cell cycle-related, antiapoptotic and invasion genes [8-13, 26, 27]. In our results, large tumor size and high Ki-67 LI indicated cell cycle progression, high Bcl-XL expression indicated antiapoptotic function, and frequent IMs indicated invasive capacity. Furthermore, high pSTAT3 expression in the lesions of IMs and
PVIs suggests that the tumor cells with STAT3 activation in the primary lesions tended to invade the vessels and metastasize to the other liver sites. Xie et al. [26, 27] reported that activated STAT3 regulated tumor invasion of melanoma cells by regulating the gene transcription of matrix metalloproteinase 2 . These results suggest that pSTAT3 expression plays an important role for cell survival and migration in HCC, consistent with previous studies in HCC $[14,17,28,29]$ and other tumors [5, 8-12, $26,27,30]$.

In recent years, it has been recognized that the balance between tumor immunity and tumor progression is important [31]. The present study revealed that tumor-associated macrophages are important for pSTAT3 expression of tumor cells. First, CD163-positive cells around pSTAT3-positive HCC cells were statistically more prevalent than around pSTAT3-negative HCC cells. Some of the CD163-positive cells expressed IL-6 in HCC tissue, and STAT3 was phosphorylated by IL- 6 stimulation in vitro. These results suggest that tumor-associated macrophages can activate HCC cells via STAT3 signaling by IL-6 expression. However, CD-163-positive cells were detected not only in the pSTAT3-negative tumor area but 
also in the pSTAT3-positive tumor area and in noncancerous liver tissue. IL-6-secreting tumor-associated macrophages may be part of the CD163-positive cells, and the CD163-positive cells in the pSTAT3-positive tumor area were more stained by IL- 6 than in the pSTAT3-negative tumor area and normal liver tissue (data not shown). Tumor-associated macrophages express immunosuppressive cytokines including IL-4, IL-6, IL-10, IL-17, and IL$23[32,33]$. These cytokines activate immunosuppressive inflammatory cells such as other tumor-associated macrophages, helper $\mathrm{T}$ cells and regulatory $\mathrm{T}$ cells and suppress antitumor inflammatory cells such as lymphocytes, natural killer cells and dendritic cells [34-36]. Kuang et al. [32] showed that tumor-associated macrophages expressed IL-6 in vitro, whereas Ding et al. [21] reported that tumor-associated macrophage was correlated with poor prognosis in HCC. Our results are consistent with these previous reports.

Both proliferation and migration of $\mathrm{PLC} / \mathrm{RPF} / 5$ and Huh7 were increased following IL-6 stimulation and STAT3 phosphorylation. On the other hand, IL-6 was expressed in not only macrophages but also in HCC cells. STAT3 can be activated through autocrine signaling in HCC cells; moreover, other cytokines and growth factors might activate STAT3 of tumor cells [22-24]. It is very difficult to exclude activation of STAT3 by the autocrine manner. In our data, STAT3 activation of HCC cells was not correlated with surrounding IL-6-positive normal hepatocytes and HCC cells but it was correlated with the infiltration of CD-163-positive cells (fig. 2). Thus, we thought that the IL-6 secretion of tumor-associated macrophages is more important for STAT3 activation of HCC cells than the IL- 6 secretion of other cells.
Recently, STAT3 phosphorylation inhibitors such as S3I-201 have been investigated in vitro and in vivo [2830]. Avella et al. [37] reported that STAT3 can be one of the targets of chemoimmunotherapies. In our study, S3I201 inhibited IL-6-induced STAT3 phosphorylation in vitro and decreased cell proliferation and migration. The inhibition of tumor-associated macrophages as therapeutic strategy of malignancy has been investigated, too [38-41]. Therefore, it is very important to suppress tumor-associated macrophage activation and STAT3 signaling in the treatment of HCC. Furthermore, tumorassociated macrophage activation requires STAT3 signaling [22]. We consider that the STAT3 inhibitor may suppress STAT3 activation in both tumor cells and tumor-associated macrophages, release antitumor immune systems from suppression by tumor-associated macrophages and thereby control tumor progression of HCC. Therefore, STAT3 signaling is a feasible therapeutic target for HCC.

In conclusion, STAT3 activation is one of the prognostic factors in HCC. Tumor-associated macrophage expresses IL-6 and can activate STAT3 signaling of HCC cells, resulting in their cell proliferation, antiapoptosis and migration. In the future, HCC may be suppressed by inhibition of STAT3 signaling of tumor cells and tumorassociated macrophages.

\section{Disclosure Statement}

The authors have no conflicts of interest.

\section{References}

1 Llovet JM, Burroughs A, Bruix J: Hepatocellular carcinoma. Lancet 2003;362:1907-1917.

-2 Shirabe K, Kanematsu T, Matumata T, Adachi E, Akazawa K, Sugimachi K: Factors linked to early recurrence of small hepatocellular carcioma after hepatectomy: univariate and multivariate analyses. Hepatology 1991; 14:802-805.

-3 Taura K, Ikai I, Hatano E, Fujii H, Uyama N, Shimahara Y: Implication of frequent local ablation therapy for intrahepatic recurrence in prolonged survival of patients with hepatocellular carcinoma undergoing hepatic resection: an analysis of 610 patients over 16 years old. Ann Surg 2006;244:265-273.
4 Llovet JM, Ricci S, Mazzaferro V, Hilgard P, Gane E, Blanc JF, de Oliveira AC, Santoro A, Raoul JL, Forner A, Schwartz M, Porta C, Zeuzem S, Bolondi L, Greten TF, Galle PR, Seitz JF, Borbath I, Häussinger D, Giannaris T, Shan M, Moscovici M, Voliotis D, Bruix J, SHARP Investigators Study Group: Sorafenib in advanced hepatocellular carcinoma. N Engl J Med 2008;359:378-390.
Bromberg JF, Wrzeszczynska MH, Devgan G, Zhao Y, Pestell RG, Albanese C, Darnell JE Jr: Stat3 as an oncogene. Cell 1999;98:295-303.

6 Al Zaid Siddiquee K, Turkson J: STAT3 as a target for inducing apoptosis in solid and hematological tumors. Cell Res 2008;18:254-267.

7 Murray PJ: The JAK-STAT signaling pathway: input and output integration. J Immunol 2007;178:2623-2629.

$\checkmark 8$ Berishaj M, Gao SP, Ahmed S, Leslie K, AlAhmadie H, Gerald WL, Bornmann W, Bromberg JF: Stat3 is tyrosine-phosphorylated through the interleukin-6/glycoprotein $130 /$ Janus kinase pathway in breast cancer. Breast Cancer Res 2007;9:R32. 
-9 Lin Q, Lai R, Chirieac LR, Li C, Thomazy VA, 20 Siveen KS, Kuttan G: Role of macrophages in Grammatikakis I, Rassidakis GZ, Zhang W, Fujio Y, Kunisada K, Hamilton SR, Amin HM: Constitutive activation of JAK3/STAT3 in colon carcinoma tumors and cell lines: inhibition of JAK3/STAT3 signaling induces apoptosis and cell cycle arrest of colon carcinoma cells. Am J Pathol 2005;167:969-980.

$>10$ Song L, Turkson J, Karras JG, Jove R, Haura EB: Activation of Stat 3 by receptor tyrosine kinases and cytokines regulates survival in human non-small cell carcinoma cells. Oncogene 2003;22:4150-4165.

$\checkmark 11$ Greten FR, Weber CK, Greten TF, Schneider G, Wagner M, Adler G, Schmid RM: Stat3 and NF-kappaB activation prevents apoptosis in pancreatic carcinogenesis. Gastroenterology 2002;123:2052-2063.

-12 Ni Z, Lou W, Leman ES, Gao AC: Inhibition of constitutively activated Stat3 signaling pathway suppresses growth of prostate cancer cells. Cancer Res 2000;60:1225-1228.

-13 Kreis S, Munz GA, Haan S, Heinrich PC, Behrmann I: Cell density dependent increase of constitutive signal transducers and activators of transcription 3 activity in melanoma cells is mediated by Janus kinases. Mol Cancer Res 2007;5:1331-1341.

14 Rajendran P, Ong TH, Chen L, Li F, Shanmugam MK, Vali S, Abbasi T, Kapoor S, Sharma A, Kumar AP, Hui KM, Sethi G: Suppression of signal transducer and activator of transcription 3 activation by butein inhibits growth of human hepatocellular carcinoma in vivo. Clin Cancer Res 2011;17:1425-1439.

-15 Yang SF, Wang SN, Wu CF, Yeh YT, Chai CY, Chunag SC, Sheen MC, Lee KT: Altered pSTAT3 (Tyr705) expression is associated with histological grading and intratumour microvessel density in hepatocellular carcinoma. J Clin Pathol 2007;60:642-648.

16 Ogata H, Kobayashi T, Chinen T, Takaki H, Sanada T, Minoda Y, Koga K, Takaesu G, Maehara Y, Iida M, Yoshimura A: Deletion of the SOCS3 gene in liver parenchymal cells promotes hepatitis-induced hepatocarcinogenesis. Gastroenterology 2006;131:179-193.

$\checkmark 17$ Pollard JW: Tumour-educated macrophages promote tumour progression and metastasis. Nat Rev Cancer 2004;4:71-78.

18 Lewis CE, Pollard JW: Distinct role of macrophages in different tumor microenvironments. Cancer Res 2006;66:605-612.

$>19$ Hasita H, Komohara Y, Okabe H, Masuda T, Ohnishi K, Lei XF, Beppu T, Baba H, Takeya $\mathrm{M}$ : Significance of alternatively activated macrophages in patients with intrahepatic cholangiocarcinoma. Cancer Sci 2010;101: 1913-1919. tumor progression. Immunol Letter 2009; 123:97-102.

21 Ding T, Xu J, Wang F, Shi M, Zhang Y, Li SP, Zheng L: High tumor-infiltrating macrophage density predicts poor prognosis in patients with primary hepatocellular carcinoma after resection. Hum Pathol 2009;40:381-389.

22 Fujiwara Y, Komohara Y, Ikeda T, Takeya M: Corosolic acid inhibits glioblastoma cell proliferation by suppressing the activation of signal transducer and activator of transcription-3 and nuclear factor-kappa B in tumor cells and tumor-associated macrophages. Cancer Sci 2011;102:206-211.

23 Takaishi K, Komohara Y, Tashiro H, Ohtake H, Nakagawa T, Katabuchi H, Takeya M: Involvement of M2-polarized macrophages in the ascites from advanced epithelial ovarian carcinoma in tumor progression via Stat 3 ac tivation. Cancer Sci 2010;101:2128-2136.

-24 Domínguez-Soto A, Sierra-Filardi E, PuigKröger A, Pérez-Maceda B, Gómez-Aguado F, Corcuera MT, Sánchez-Mateos P, Corbí AL: Dendritic cell-specific ICAM-3-grabbing nonintegrin expression on M2-polarized and tumor-associated macrophages is macrophage-CSF dependent and enhanced by tumor-derived IL-6 and IL-10. J Immunol 2011; 186:2192-2200.

25 Komohara Y, Ohnishi K, Kuratsu J, Takeya M: Possible involvement of the M2 anti-inflammatory macrophage phenotype in growth of human gliomas. J Pathol 2008;216: 15-24.

26 Xie TX, Wei D, Liu M, Gao AC, Ali-Osman F, Sawaya R, Huang S: Stat3 activation regulates the expression of matrix metalloproteinase-2 and tumor invasion and metastasis. Oncogene 2004;23:3550-3560.

-27 Xie TX, Huang FJ, Aldape KD, Kang SH, Liu M, Gershenwald JE, Xie K, Sawaya R, Huang S: Activation of Stat 3 in human melanoma promotes brain metastasis. Cancer Res 2006; 66:3188-3196.

28 Lin L, Amin R, Gallicano GI, Glasgow E, Jogunoori W, Jessup JM, Zasloff M, Marshall JL, Shetty K, Johnson L, Mishra L, He AR: The STAT3 inhibitor NSC 74859 is effective in hepatocellular cancers with disrupted TGF-beta signaling. Oncogene 2009;28:961-972.

29 Choudhari SR, Khan MA, Harris G, Picker D, Jacob GS, Block T, Shailubhai K: Deactivation of Akt and STAT3 signalling promotes apoptosis, inhibits proliferation, and enhances the sensitivity of hepatocellular carcinoma cells to an anticancer agent, Atiprimod. Mol Cancer Ther 2007;6:112-121.

30 Lin L, Hutzen B, Zuo M, Ball S, Deangelis S, Foust E, Pandit B, Ihnat MA, Shenoy SS, Kulp S, Li PK, Li C, Fuchs J, Lin J: Novel STAT3 phosphorylation inhibitors exhibit potent growth-suppressive activity in pancreatic and breast cancer cells. Cancer Res 2010;70:24452454.
31 Korangy F, Höchst B, Manns MP, Greten TF: Immune responses in hepatocellular carcinoma. Dig Dis 2010;28:150-154.

32 Kuang DM, Peng C, Zhao Q, Wu Y, Chen MS, Zheng L: Activated monocytes in peritumoral stroma of hepatocellular carcinoma promote expansion of memory T helper 17 cells. Hepatology 2010;51:154-164.

33 Kortylewski M, Xin H, Kujawski M, Lee H, Liu Y, Harris T, Drake C, Pardoll D, Yu H: Regulation of the IL-23 and IL-23 balance by Stat3 signaling in the tumor microenvironment. Cancer Cell 2009;15:114-123.

34 Kuang DM, Zhao Q, Peng C, Xu J, Zhang JP, $\mathrm{Wu}$ C, Zheng L: Activated monocytes in peritumoral stroma of hepatocellular carcinoma foster immune privilege and disease progression through PD-L1. J Exp Med 2009;206: 1327-1337.

35 Wu K, Kryczek I, Chen L, Zou W, Welling TH: Kupffer cell suppression of CD8+ T cells in human hepatocellular carcinoma is mediated by $\mathrm{B} 7-\mathrm{H} 1 /$ programmed death- 1 interactions. Cancer Res 2009;69:8067-8075.

-36 Niemand C, Nimmesgern A, Haan S, Fischer P, Schaper F, Rossaint R, Heinrich PC, MüllerNewen G: Activation of STAT3 by IL- 6 and IL10 in primary human macrophages is differentially modulated by suppressor of cytokine signaling 3. J Immunol 2003;170:3263-3272.

37 Avella DM, Li G, Schell TD, Liu D, Zhang SS, Lou X, Berg A, Kimchi ET, Tagaram HR, Yang Q, Shereef S, Garcia LS, Kester M, Isom HC, Rountree CB, Staveley-O'Carroll KF: Regression of established hepatocellular carcinoma is induced by chemoimmunotherapy in an orthotopic murine model. Hepatology 2012;55:141-152.

38 Zhang W, Zhu XD, Sun HC, Xiong YQ, Zhuang PY, Xu HX, Kong LQ, Wang L, Wu WZ, Tang ZY: Depletion of tumor-associated macrophages enhances the effect of sorafenib in metastatic liver cancer models by antimetastatic and antiangiogenic effects. Clin Cancer Res 2010;16:3420-3430.

39 Luo Y, Zhou H, Krueger J, Kaplan C, Lee SH, Dolman C, Markowitz D, Wu W, Liu C, Reisfeld RA, Xiang R: Targeting tumor-associated macrophages as a novel strategy against breast cancer. J Clin Invest 2006;116:2132-2141.

40 Huang Y, Snuderl M, Jain RK: Polarization of tumor-associated macrophages: a novel strategy for vascular normalization and antitumor immunity. Cancer Cell 2011;19:1-2.

41 Wu WY, Li J, Wu ZS, Zhang CL, Meng XL: STAT3 activation in monocytes accelerates liver cancer progression. BMC Cancer 2011; 11:506. 